\title{
The Pure Theory of Law: Demythologizing Legal Thought
}

\author{
William Ebenstein*
}

I

A NeW Theory of LAW: AN OVERVIEW

\section{A. Background}

The appearance in 1911 of Hans Kelsen's first major work, Hauptprobleme der Staatsrechtslehre, a massive toine of over 700 pages, inaugurated a new era in the field of legal theory. Although the author of Hauptprobleme was barely 30 years of age when it was published, he had the good fortune of immediately receiving widespread attention. Because many of Kelsen's basic views and methods of analysis ran counter to tradition and were often outright iconoclastic, the first reactions were often critical and even hostile, thus indicating that Kelsen's approaches to the chief problems of law and the state had offended traditional legal and political theories. Yet reactions of approval and encouragement were not lacking; particularly among more philosophically inclined reviewers there were those who hailed the work as "an energetic and logical attempt to translate transcendentalism into the philosophy of law." It was not surprising that, among the philosophically oriented critics and reviewers of Kelsen, followers of Kant and neo-Kantianism felt most sympathetically attracted to him, since his methods of thought and analysis suggested a profound affinity with Kantian categories of critical philosophy.

Kelsen's influence grew rapidly, partly because his highly prolific literary output on key aspects of law and the state showed the applicability of his Pure Theory of Law to many intricate specific problems, and partly because he was joined by a group of able jurists who, without necessarily identifying theinselves unqualifiedly with Kelsen, associated themselves with his endeavor to build a theory of law on solid

* Professor of Political Science, University of California, Santa Barbara. LL.D. 1934, University of Vienna; Ph.D. 1938, University of Wisconsin. (1912).

1. Ewald, Die deutsche Philosophie im Jahre 1911, 17 KANT-STudIEN 382, 397 
philosophical foundations. Among the most outstanding members of the Vienna School of Law-as the movement of the Pure Theory of Law was first known-were Alfred Verdross and Josef L. Kunz, both primarily interested in international law; Adolf Merkl, a creative scholar and thinker in the field of administrative law; and Felix Kaufmann and Fritz Schreier, who as followers of Edmund Husserl sought to assimilate phenomenological analyses in the formulation of a general theory of law.

The rapid growth of the influence of the Vienna School of Law and its guiding spirit, Kelsen, was temporarily interrupted by the First World War. After the war, however, Kelsen's writings became even more widely influential, or were at least more widely discussed in the new post-war intellectual chimate in Central Europe. In 1925, Kelsen's Allgemeine Staatslehre (General Theory of the State) was published as volume XXIII in the Enzyklopädie der Rechts- und Staatswissenschaft, the standard German-language series in the legal, pohtical, and social sciences. The choice of Kelsen for the authorship of a work on the general theory of public law and the state did not signify that the academic Establishment had become converted to his ideas, but acknowledged the fact that his views were more widely debated, challenged, and criticized than those of any other scholar in the field then writing in the German language.

As Kelsen's philosophical approaches to the general theory of law aroused interest beyond Central Europe, the name of the movement was increasingly referred to as The Pure Theory of Law rather than the Vienna School of Law. Kelsen himself had left Austria at the end of the 1920's to occupy a chair at the University of Cologne. The Nazification of Germany in 1933 forced him to leave Germany, and after tejnporary sojourns in various European countries, he finally settled in the United States. He concluded his official academic career at the University of California at Berkeley in 1952.

The necessity of exile also befell other leading representatives of the Pure Theory of Law, many of whom migrated to Enghish-speaking countries, particularly the United States and Great Britain. Thus, as a result of the upheavals in Europe in the 1930's and 1940's, numerous scholars associated with the Pure Theory of Law became exposed to the new environment of the common law in both practice and theory, and jurists and legal thinkers in common-law countries found themselves increasingly stimulated and challenged by the intensified exposure to the Pure Theory and its concern with basic philosophical issues. The exchange was inutually fruitful. If Continental European jurists can be charged with having lost themselves at times too deeply in the labyrinths of barren conceptual and pseudo-philosophical speculations, lawyers in 
the common-law countries have seldom suffered from an excessively intense concern with basic philosophical and theoretical problems of jurisprudence.

Although when first introduced, the Pure Theory of Law was frequently dismissed-more on the basis of hearsay than of careful analysis-as but another case of typical, overly conceptualized continental jurisprudence, American and British jurists gradually realized that the Pure Theory of Law transcends the limitations and built-in biases of continental legal ideas and institutions, and that it has many points of similarity with the traditions and assumptions of the common law. In many areas of the legal process-both with respect to legal principles and legal institutions of the common law-the Pure Theory has sharpened and clarified insights of lawyers previously perceived only through experience, habit, and common sense rather than rigorous and systematic analysis. Dean Roscoe Pound, then one of the foremost American jurists, called Kelsen in 1934 "unquestionably the leading jurist of the time,"2 although Pound neither followed nor strongly sympathized with the Pure Theory of Law. Dean Pound showed remarkable farsightedness, for at that time Kelsen and his main associates were still on the Continent, and relatively few of their writings had been translated into Enghish.

Subsequently, as Kelsen and many of his followers moved froin the Continent to the United States and other English-speaking countries, and as they began to publish major books and articles in English, the gap of mutual misunderstanding between the Pure Theory of Law and Anglo-American legal theory gradually narrowed. If Dean Pound's statement about Kelsen's leading role was true in the 1930's, it is even more tenable in the 1970's, after nearly four decades of mutual contact and scholarly exchange between jurists raised in the diverse traditions and outlooks of the civil law and the common law. Having started at an early age in his writing career and continued it over a period of more than 60 years, Kelsen has published hundreds of books and articles, many of them translated into more than two dozen languages throughout the world. Now, at the revered age of 90, Kelsen stands out as the towering figure in 20th-century legal thought, not as the author of a new orthodxy that is bound to become sterile and obsolete with the passage of time, but as a critical thinker who cannot be by-

2. Pound, Law and the Science of Law in Recent Theories, 43 YALE L.J. 525, 532 (1934). Similarly, Professor Patterson has observed: "Probably no legal-political philosoplier of the present century has attained more world-wide fame than has $\mathrm{Dr}$. Hans Kelsen." Patterson, Hans Kelsen and His Pure Theory of Law, 40 CAIIF. L. REv. 5, 6 (1952). An English jurist, H.L.A. Hart, calls Kelsen "the most stimulating writer on analytical jurisprudence of our day." Hart, Kelsen Visited, 10 U.C.L.A.L. REv. 709, 728 (1963). 
passed by any writer on basic issues of legal theory, regardless of whether one agrees with the main methods of inquiry and conclusions of the Pure Theory of Law.

Throughout his long writing career, Kelsen's main works have dealt with basic problems of the general theory of law and the state, culminating, in 1945, in his General Theory of Law and State, and, in 1960, in the second and greatly revised and enlarged edition of Reine Rechtslehre, whose English translation by Max Knight appeared in 1967 under the title, The Pure Theory of Law, and under the imprint of the University of California Press. ${ }^{3}$ While Kelsen's most creative contributions lie in the field of legal theory, his range of interests broadened, particularly in the middle and later periods of his career when he explored the philosophical and historical evolution both of great political thinkers-such as Plato and Aristotle - and of fundamental political ideas and systems-such as dennocracy, parliamentary government, socialism, communism, and totalitarianism. ${ }^{5}$ His interest in psychology resulted in his examination of the relations of social psychology to basic concepts of law and the state, ${ }^{6}$ either in the form of special monographs or by incorporating such analyses in his more general works. A student of religion and theology, Kelsen also investigated some problems of positive law, justice, and natural law in the hight of the Old and New Testaments. ${ }^{7}$ Finally, his interest in the evolution of the fundamental categories of thought in the physical and social sciences led him to the study of anthropology and early ("pre-civilized") history, from which he derived some fresli insights into the development and meaning of causality in the physical world and of responsibility-or "imputation"-in the ethical and normative realms. ${ }^{8}$

3. Although Kelsen's style in German is clear and incisive, eschewing the typical vagaries and obscurities of academic German, it is not easy to re-create in English. The translator deserves to be commended for his ability to render Kelsen's thought and diction in an English version worthy of the original. Regrettably, though, the translation lacks the Appendix to Reine Rechtslehre, in which Kelsen deals with "The Problem of Justice." H. KelSEN, ReINe RechtsLEHRE 357-444 (1960) [hereinafter cited as Reine Rechtslehre]. However, the interested reader will find, in English, a treatment of the problems of justice and natural law in H. KeLSEN, GENERAL THEORY OF LAW AND STATE 391-446 (1945).

4. See, e.g., Kelsen, Platonic Love, 3 AMERICAN Imago 3 (1942).

5. See, e.g., H. Kelsen, The Communist Theorx of LAw (1955); H. Kelsen, The Political Theory of Bolshevism (1948); Kelsen, Foundations of Democracy, 66 ETracs 1 (1955); Kelsen, The Party-Dictatorship, 2 PoLITICA 19 (1936).

6. Kelsen, The Conception of the State and Social Psychology, 5 INT'L J. Psycho-Analysis 1 (1924).

7. E.g., Kelsen, The Soul and the Law, 1 Rev. ReIIGION 337 (1937).

8. E.g., H. KEISEN, SOCIETY AND NATURE (1943). Other books by Kelsen that have been published in English are: GENERAr ThEORY OF LAW AND STATE (1945); PRINCIPLes OF INTERNATIONAL LAW (1952; 2d ed. rev. 1966); The LAW OF THE UNITED Nations (1950); What Is Justice (1957). The most complete bibliography of Kel- 
Kelsen's life-long interest in legal theory-the most pervasive and enduring of his commitments as a scholar and writer-was strongly buttressed by an intense interest in positive law, both as a student of positive legal rules and institutions and as an active participant in the creation and interpretation of law. Kelsen was the main author of the Austrian Constitution of 1920 , which is substantially still in force, and he served as a Permanent Counsellor to the Austrian Constitutional Court from 1920 to $1929 . .^{\circ}$ As a student of positive law, he wrote voluminously on Austrian public and constitutional law, and was regarded in Austria as one of the leading authorities in the field. Later, he turned his attention to positive international law and the law of the United Nations, contributing numerous monographic studies and standard treatises. ${ }^{10}$

\section{B. Philosophical Foundations of the Pure Theory}

From its inception, Kelsen's Pure Theory of Law has been strongly influenced by Kantian epistemology. After a temporary decline of Kantianism in the first half of the 19th century, the rapid growth of science-particularly the physical sciences-in the second half of the 19th century awakened a renewed interest in philosophy of science. Kant had first sought to establish, through the critical nnethod of his Critique of Pure Reason, the possibilities and limitations of knowledge of the external physical world, leaving to the various disciplines in the physical sciences the task of finding concrete knowledge. Kant demonstrated that the metaphysical search for the knowledge of the transcendent, "true" reality, the "thing in itself," was fruitless and unattainable by the human mind. Instead, he formulated the "transcendental logical categories"-such as space, time, and causality-which are not empirical laws, but which make experience possible, and by means of which an aggregate of individual phenomena, a chaos of sensory perceptions, can be comprehended as a meaningful whole, as a cosmos, as "nature" in the scientific sense of a systent of general laws and principles.

From Kant-and even inore froin neo-Kantians such as Herinann Cohen and Ernst Cassirer-Kelsen acquired a deep sense of the creative function of scientific cognition and of the importance of inethod and methodological purity in scientific analysis. According to this view, since the "thing in itself" is unknowable, the object of cognition is logically "created" by the knowing subject. This creation has a purely epistemological character, and must be distinguished from tangible objects

sen's writings is in REINE RECHTSLEHRE, 501-31; this bibliography is not included in The Pure Theory of Law.

9. Kelsen, Judicial Review of Legislation, 4 J. Polrmics 183 (1942).

10. See note 8 supra. 
created by human labor or froin intangible things, such as laws passed by a legislative body. The neo-Kantians, particularly Cassirer, also pointed the way to resolve the age-old dualism between substance and function, since substantivist thinking -in the physical as well as in the social and normative sciences-is often the last line of defense of residual inetaphysical speculation. Cassirer emphasized the general tendency in modern science to dissolve traditional concepts of sciencesuch as inatter, energy, force, and the atom-into nonsubstantive concepts of relations, functions, and events. ${ }^{11}$

Similarly, Kelsen showed in his juristic analysis that traditional concepts like state, person, and other substantive terms are nothing but reifications or personifications of functions and relationships, and that soine of the traditional dualisms-such as those between state and law, public and private law, physical and legal person-are false dualisms, based either on faulty theory or on politically motivated ideology. For example, the alleged duahism between state and law does not exist, for the state and law-national law-are identical, and therefore there can be no problein of relations between the two. In addition to pointing out the false analytical basis of the dualism of state and law, Kelsen notes its ideological function of justifying the state as a "community governed by law (Rechtsstaat)."12

While fully recognizing the importance of the Kantian philosophy of science, Kelsen was no inere follower of Kant. In Kelsen's view, Kant had waged the struggle against metaphysics only in his theoretical philosophy relating to phenomena in the physical world. On the other liand, in Kant's practical philosophy, relating to morals and law, he adhered to a traditional metaphysical outlook as expressed in his Metaphysics of Ethics. Kant thus failed to carry his critical philosophy to its conclusion where law and inorals were concerned, since he was too deeply rooted in Christianity, and as a legal philosopher he remained faithful to the doctrine of natural law. Indeed, Metaphysics of Ethics may be regarded, Kelsen writes, "as the most perfect expression of the classical doctrine of natural law as it evolved in the seventeenth and eighteenth centuries on the basis of Protestant Christianity."13 Kelsen's work in legal theory throughout his whole life may be regarded as an attempt to do what Kant himself failed to do-to construct a theory of law along the lines of Kantian critical philosophy which would en-

11. See E. Cassirer, Substance and Function and Einstein's Theory of RELATTVITY (1923) (originally published in German as two separate works in 1910 and 1921).

12. H. Kelsen, The PURe Theory of Law 285 (1967).

13. H. Kelsen, General Theory of Law and State 445 .(1945). See also REINE ReCHTSLEHRE 420-25 (1960). 
able legal science to come to grips with legal data and integrate them into a unified system.

\section{Cognition and Ideology}

The Pure Theory of Law is seen by Kelsen as a general theory of positive law. It is concerned with law in general rather than with a specific legal norm or legal order. It is concerned with positive law, law as it is rather than as it ought to be. In stressing the nature of the Pure Theory of Law as a theory, Kelsen relies on the basic Kantian distinction between cognition and volition, corresponding to the Kantian juxtaposition of theoretical and practical reason. The separation of cognition from volition is expressed on the one hand in the distinction between science and ideology, and on the other in the distinction between theory and practice. Every political ideology or doctrine of natural law has its roots in volition rather than in cognition. Its aim is not to understand the law, its structure and forms, but to deny its reality. Ideology can do this in two ways. It either veils legal reality by justifying an existing legal order and by identifying it more or less with a higher, ideal law-the conservative version of all political ideologies and natural law doctrines-or it denigrates legal reality with the objective of replacing it with another legal order. By contrast, cognitive analysis, or science-imcluding the science of law-aims solely at unveiling its subject of cognition, refusing, unlike ideology, to serve social, economic, political, or other interests except the interest of cognitive truth. Kelsen is aware that truth, too, is an interest, but he does not claim that the interest of truth has an intrinsically higher value or dignity than other interests. His point is inerely to stress that there is a real and important difference between the interest in searching for truth and the interest im promoting political, social, or economic goals. If there is to be a science of law, this separation between interest in truth and interests in political justification or change must, therefore, always be kept clearly im mind.

The problem of keeping ideological and political elements out of theoretical cognition is not pecuhar to legal science, but applies to all sciences, physical as well as social. At one time, the physical and biological sciences, too, had to wage a struggle against political and ideological interference. If that struggle was finally won, the victory was due to the fact that powerful social groups were keenly interested in it because successful technological and economic advance depended on the freedom of science. As yet, there lias developed, with respect to the social sciences-including the science of law-no social group powerful enougl to insist on freedom from ideology and pohtics, smce both those who wield power and those who aspire to it prefer theories serv- 
ing their political ends to theories that unveil the realities of the social and legal order. Moreover, because the social sciences are still relatively underdeveloped, there is in social and legal theory no such direct path to practical benefits as exists in the natural sciences. This comparative retardation inhibits the growth of powerful social groups to defend the developinent of a social and legal science free from ideology.

As a witness of wars, civil wars, revolutions, and totalitarian regimes, Kelsen maintains that ideology-free sciences of society can flourish only in relatively stable social and political systems, smce stabilized political power that can rely on widespread consent needs the underpinnings of ideology less than do political systems that are rift by internal conflict and rely on terror for survival and continuity. In 1945, in his Preface to General Theory of Law and State, Kelsen expressed the view that freedom of social and legal science would be most respected in the Anglo-American world, with its greater stability of political power. He added the liope that in a liberated Europe an independent science of law would have a new opportunity. In 1960, in his Preface to the second edition of Reine Rechtslehre in German, Kelsen expressed a more pessimistic outlook, noting that the interstate and intrastate divisions and conflicts after World War II were not too dissimilar from those produced by World War I, and also pointing to a revival of metaphysics and natural law doctrines as obstacles to an ideology-free science of the law. Stressing the outspoken anti-ideological tendency of the Pure Theory of Law, Kelsen calls the theory "a radical realistic theory of law, that is, a theory of legal positivism."14

Closely related to the conceptual dichotomy of cognition and volition which underlies the foundations of Kelsen's legal thought and his methodology is that between reason and enotion. Kelsen notes that Kant, in his Critique of Practical Reason and Metaphysics of Ethics, was aware of the difference between reason and emotion but failed to keep them distinct in his practical philosophy of ethics and law. Here again, Kelsen seeks to carry Kantian concepts through to their logical conclusion. Conflicts of interest in society must ultimately be resolved by sacrificing one interest to another, but this can be done only by deciding which of the competing interests has a higher value.

However, rational cognition cannot supply a solution as to which value is higher since judgments of value are determined by subjective einotional criteria. Kelsen writes:

If somebody says that something is good or bad, but if this state-

14. H. KELSEN, supra note 12, at 106 . See also E. BoDENHEIMER, JURISPRUDENCE 101 (1962) (referring to the Pure Thoery of Law as "perhaps the most consistent expression of positivism in legal theory.") 
ment is merely the immediate expression of his emotional attitude toward a certain object, if it expresses that he wishes something or does not wish it but its contrary, then the statement is no value "judgment," because it is not a function of cognition, but a function of the emotional component of consciousness; and if this emotional reaction refers to the behavior of another individual, then it is the expression of an emotional approval or disapproval, akin to the exclamation "bravo!" or "phooey!"15

This particular expression of the unbridgeable gulf between cognition and emotion by Kelsen is akin to some of the basic positions and formulations of Logical Positivism, particularly its emotive theory of values. ${ }^{16}$ Kelsen's anti-metaphysical outlook attests to a deep affmity with that of Logical Positivism, but there are also fundamental differences, particularly with respect to the logical structure of norms. Specifically, Kelsen parts company with the Logical Positivists when they add to their anti-metaphysical position an anti-normative stance by denying the very existence of norms which are viewed by them as mere factual data. This runs counter to Kelsen's persistent emphasis on the gulf between fact and norm, the Is and the Ought.

\section{Law, Morality, and Religion}

In defining the Pure Theory of Law as a general theory of positive law, Kelsen first seeks to determine whether there is one element common to all legal systems at all times and at every level of cultural and political-legal development. Politically or ideologically colored defmitions of law invariably introduce substantive criteria. In antiquity, St. Augustine denied a political regime without justice and commitment to God the character of a legal community. In medieval times, John of Salisbury justified tyrannicide on the ground that a tyrannical regime was no legal order, and, therefore, the tyrant was an outcast from the legal community and could be lawfully done away with by force. These latter concepts were later revived by John Locke. In modern times, European governments temporarily refused to recognize the French government after the Revolution of 1789 because for many, the very concept of law entailed the principle of monarchical rule. Similarly, after the Bolshevik Revolution in 1917, some governments refused to recognize the new order as a legal government and preferred to view it, in an Augustinian manner, as but a band of gangsters.

More recently, students of the law of modern totalitarian regimes have denied that the law of Nazi Germany was law in any meaningful sense, because a legal order is not law-under a democratically oriented

15. H. KeLSEN, supra note 12, at 20.

16. See, e.g., A. Ayer, Language, Truth and Logic 107-09 (1946). 
definition of law-unless a minimum of personal liberty is safeguarded. Similarly, to Marxist jurists, a legal system that maintains private ownership of the means of production is nothing but naked force, since the Marxist concept of law is incompatible with a capitalist economic system.

In his search for a conception of law that is based on scientific universality rather than on political particularism, Kelsen defines law as a coercive order of human behavior. ${ }^{17}$ This definition is free from the last traces of traditional natural law, and even has the ring of behaviorism that flourished in the 1950's and 1960's. In his definition, Kelsen stresses the function of law as a "specific technique of social organization"18 - which is universally valid-rather than the content of law, which changes with the varying circumstances of time and place.

According to Kelsen, law is not the only system of norms that seeks to regulate human behavior: morality and religion have the same objective. But neither morality nor religion have the sanction of physical coercion if a moral or religious norm is violated. Moral norms, such as "thou shalt not steal," typically include no sanctions for immoral behavior, but merely forbid it. Inmoral behavior inay result in social disapproval and ostracism, but such sanction is neither included in the concept of a moral norm nor socially organized. As for religion, its norms are more closely related to the structure of legal norns, because religious norms hold out the sanctions of rewards and punishments in the hereafter. The coercion threatened by religious norms is therefore transcendental, and its efficacy depends on whether the person who violates them believes in God and punishments meted out in the hereafter.

The characterization of law as a coercive order does not mean that law actually enforces the legally commanded behavior, since the coercive act is to be effected only in the case of behavior which is prohibited. Kelsen admits that the threat of coercive sanctions for illegal behavior may have the psychological effect of inducing persons to act in conformity with the law. However, it is an empirical question whether the law induces this psychological motivation in a particular case, and the validity of the law and its coercive sanctions does not depend on whether it produces the motivation to act in accordance with its commands. Moreover, other orders regulating human behavior may also produce the motivation to act in conformity with the law. Kelsen argues that religion, for example, is probably a more effective psychic force than the law.

17. H. KELSEN, supra note 12 , at $31,33$.

18. H. Kelsen, General Theory of Law and State 5 (1945). 
Psychic force or motivation is thus not a fundamental criterion that distinguishes the law from other normative orders regulating human behavior, such as morality and religion. Law alone, whether it produces psychic motivation or not, is an order which prescribes, and has at its command, coercive acts-the forcible deprivation of life, hiberty, property, and other values. In accomplishing its objectives, the law uses, paradoxically, the very same modes of action-the deprivation of life, liberty, property, and other values-which it prohibits in the mutual relations between members of a society. Yet this paradox is insoluble only if one adopts the stance of anarchism accordimg to which a social order can be maintained exclusively by the voluntary obedience of its members to its rules. Yet, so far at least, there has never been an anarchist society. Thus, historical experience has vindicated the Roman notion: "Where there is society, there is law." In the light of the experience of actual societies-as opposed to societies imagined or postulated by political doctrines - the monopoly of force claimed by the legal order expresses a tendency toward collective security or peace within society.

Collective security within a society is best exemplified by fully developed legal institutions outlawing self-help and centralizing both compulsory adjudication through courts and effective enforcement through specialized executive organs. Collective security thus results in a relative economy of force, but such social peace is only relative, for absolute peace would mean no use of force at all. The relation between Recht-German for both right and law-and Macht-might, force, and power-is thus seen by Kelsen to be in a middle position between two cominonly held views: Recht is not identical with Macht, as postulated by the pohitically oriented "might makes right" scliool from Machiavelli to Hegel, nor can there be Recht without Macht, as is assumed by the future-directed ideology of anarchism. In other words, Recht "is a certain order (or organization) of might."19 This conception of law is a far cry from the age-old metaphysical quest for "the law in itself," as reflected classically in the Aristotelian-Stoic view of law as the voice of reason or $m$ the Thomistic concept of law as an ordinance of reason for the common good.

Just as Kant's critical philosophy stands midway between objective metaphysics and subjective sohpsism, aware of both the limits and potential of cognition in the physical sciences, Kelsen's concept of law stands midway between the metaplyysical doctrine of natural law and the solipsistic doctrine of anarchy without laws-or at least without coercive laws-in which everybody is doing his thing, and yet no violation of social rules occurs that must be stopped by coercive social responses.

19. H. KeLSEN, supra note 12, at 214. 
II

The Pure Theory of Law: The Structure

\section{A. The Legal Norm}

The constitutive element of Kelsen's theory of positive law is the "norm," or the rule that something ought to occur, particularly that somebody ought to act or behave in a prescribed way. The norm may also prescribe that a person may-is permitted to-or can-is authorized to-behave in a certain way. In Kelsen's conception, legal norms belong to the realm of the "ought," although linguistically this may sometimes be hidden. For example, a criminal statute might provide that a person who commits high treason "will" be punished in a prescribed manner. This linguistic imprecision does not conceal the fact that the legislator is no prophet and is not predicting future events but prescribing what ought to happen in a predetermined situation. Kelsen stresses that the "ought" in the legal norm has no ethical, moral, or natural-law connotations, but is merely a "functional connection," mode of thinking, which is given directly to our consciousness as a simple concept.

Kelsen's sharp distinction between the causal and the normative connection between two sets of propositions or facts reflects Kantian and neo-Kantian thought. The causal connection-whether in the physical or social realms-is expressed in the formula: "If A, then B." The normative connection is expressed: "If $\mathrm{A}$, then $\mathrm{B}$ ought to be." From the fact that somethng is, one cannot logically deduce that it ought to be, nor can one deduce from the fact that something ought to be that it actually will be. For Kelsen, the categories of "is" and "ought" are categories that define functional colmections in one way or the othercausal or normative-but are not susceptible of further analysis or definition, smce they are given directly to consciousness. Nature is an order of things correlated by the principle of cause and effect, the principle of causality. Moreover, this is the only principle that links things and events in nature. Observing that a metallic body expands when heated we note a cause-effect relation between the heating and expanding of the body. Whether factually true or false, this linking can only be expressed through an "is" propostion: "If A (heating), then B (expansion)." But the sentence, "A metallic body when heated ought to expand," is neither true nor false, but neaningful, since the causal "is" relation is the only one applicable in nature.

Hunian behavior, by contrast, can be the subject of two kinds of analyses and propositions. On the one hand, human behavior can be

20. Id. at 103. 
the subject of causal relations, as when an economist puts forth the proposition that, if too many buyers chase too few goods, prices will rise. The social sciences, to the extent that they seek to study human behavior in terms of the principle of causality, are, in Kelsen's view, not essentially different from natural science, although he is not sure to what extent such study has been successful so far. However, human behavior-untike the behavior of molecules or electrons-can also be perceived and interpreted, not only by means of causality, how it takes place, but also from a different perspective: how it ought to take place as predetermined by positive-man-made-laws. The very concept of society is, for Kelsen, fundamentally a normative one, since men belong to a society to the extent that their mutual behavior is regulated by a normative order. Kelsen observes:

If it is said that a certain society is constituted by a normative order regulating the mutual behavior of a multitude of men, one must remain aware that order and society are not two things; that they are one and the same thing, that society consists in nothing but this order, and that, if society is designated as a cominunity, then essentially that which these men have "in common" is nothing else but the order regulating their mutual behavior. ${ }^{21}$

If any social order is, accordmg to Kelsen, basically a normative one, the legal order shows this character with particular clarity, for the legal community constituted by the legal order includes a wide variety of groups of different interests, languages, rehigions, and viewpoints. Yet all these divergent groups and individuals form one legal community to the extent that their mutual behavior is regulated by the same normative order of positive law.

One of Kelsen's most original contributions to the clarification of the concept of the norm is his formulation of its function as a scheme of interpretation. Although the logical structure of an is-statement is fundamentally different from that of an ought-statement, this does not mean that there is no relation between them. The same behavior may appear in an is-statement that appears in an ought-statement. The statements, for example, "A debtor repays his debt to his creditor" and "A debtor ought to repay his debt to his creditor" contain the same behavior, but in the first case the behavior is expressed as something that is, whereas in the second case it is presented as something that ought to be. The actual behavior cannot be the behavior that ought to be, since an is cannot be an ought, but metaphorically or figuratively one often says that the "content" of the is-statement is the "same" as that of the ought-statement. Although this is only a not too accurate shorthand formulation, the norm allows us to compare the behavior pre-

21. Id. at 86 . 
scribed—or authorized or permitted—by it with the actual behavior. If the content of actual behavior conforms to the content of the norm, it can be interpreted as part of the normative system.

The norm thus serves as a scheine or method of interpretation. For example, if a revolutionary organization sentences a traitor to its cause to death and then executes this "death penalty," the physical elements of this killing are the same as in the killing of a person by a legally appointed executioner. Froin the causal viewpoint, both cases are alike, since in both cases a person is being put to death. Yet, the former killing is unlawful and the latter lawful, because the meaning of the act of execution is derived from the fact that it is part of the legal system that has ordered the executioner to perform his act. In a true Kantian manner, Kelsen argues that phenomena have no meaning in themselves; by looking at thein from the viewpoint of causality, we confer on events, acts, and phenomena a meaning from the perspective of the natural sciences. However, if we look at the same acts from a normative, or legal viewpoint, we endow them with a different kind of meaning which cannot be perceived by our senses, but is the result of a thinking process through which we discover whether a particular act is legal or illegal.

In conferring normative meaning on human acts, the legal norm is not different from the moral norm; the moral ineaning of a human act cannot be perceived by the senses, but can be arrived at only by comparing the act with the content of the moral norm. For example, the moral meaning of the act of a burglar in removing goods from a home cannot be deduced through sensory perceptions. These provide only an understanding of the act in terms of time and space by applying the primciple of causahty. But if there is a moral norm, "Thou shalt not steal," it is possible to examine whether the act of the burglar conforms to, or violates, the content of that unoral norm. As a scheme of interpretation, the moral norm is akin to the legal norm. But there is a basic difference of structure. A moral norm, such as "Thou shalt not steal," does not attach a punitive or coercive consequence to the act of stealing, because, as seen earlier, the moral order is not a coercive order, although society, or some members of society, may display disapproval or ostracisin of a person who violates a moral norm.

\section{B. Structure of the Legal Norm}

In contrast to that of a moral norm, the structure of a legal normregardless of its linguistic formulation-runs thus: "If a person steals, the competent organ or agent of the state ought to apply the penalty stipulated by law." The illegal act-crime or tort-is called by Kelsen the "delict"; the consequence threatened or stipulated by the norm is called 
the "sanction." In Kelsen's ingenious conception of the structure of the norm, the legal order is directly concerned, not with human behavior that conforms to the law, but with behavior that is in opposition to it. Largely under the influence of morality, religion, and natural law, traditional conceptions view the positive law as a system of commands, deriving its obligatory character from the binding force of such moral concepts as duty and obligation. The legal ouglit then derives its strength from the fact that it partakes-in a more or less openly admitted manner-of the moral or rehigious ought. Ideally, from this traditional jurisprudential viewpoint permeated with natural-law elements, the positive law is the more perfect the more its rules coincide with those of morality and religion.

In Kelsen's construction of the legal norm, the theoretical and psychological confusion between the legal order as a coercive social order and other normative orders such as inorality and religion is removed in two ways. First, the ought in the legal norm refers, not to the behavior that the legal order aims at, but to the sanction whicl is to be applied in case of contra-legal behavior-to the action prescribed for the state authority by the sanction. The contra-legal behavior-the first structural half of the norm-is but a condition for the sanction. A civil code, for example, may liave the norm that a debtor ought to repay a loan to his creditor; but such a norm is, in itself, not a legal norm for no coercive consequence is attached to behavior contrary to that norm. However, if the same civil code has a norm stipulating that if a debtor does not repay his loan, the court shall order civil execution on his property, then the first norm - "A debtor ought to repay his loan to the creditor"is superfluous, since it is included as a condition of the sanction in the second norm. Similarly, in criminal law, a legal norm, "You shall not commit murder" is superfluous, if there is a valid norm stating: "If a person commits murder, the competent organ of the state shall apply the legally prescribed sanction."

Moreover, the conditional element in the norm on the basis of which the sanction ought to be applied need not be an act, as is the case in the normative orders of morality and rehgion. Totalitarian states imprison and kill persons not only because they commit acts considered harmful but because they belong to certam religious, racial, or social groups. Thus, a person is punished not for what he does but for what he is. Nontotalitarian states imprison resident citizens of enemy nationality at the outbreak of war, not for what they liave done but for wliat they might do. All types of states imprison persons when there is only the suspicion of their having committed serious offenses against the legal order. Persons that suffer from mental illness or are afflicted with contagious diseases may also be deprived of their liberty 
if they are considered a threat to public lealth and safety. Finally, the state-under any form of government-may expropriate private property in the public interest, or may demolish buildings if they are in danger of collapsing.

In all these instances, the coercive act of the legal order takes placeor, more accurately, ought to take place-even if there has been no human act. Kelsen therefore suggests that the concept of sanction "may be extended to include all coercive acts established by the legal order, if the word is to express merely that the legal order reacts with this action against socially undesirable circumstances and qualifies in this way the circumstances as undesirable."22 Human beliavior may typically be the content of the circumstances (Sachverhalt) which condition the coercive legal act, but this would only constitute statistical frequency, not logical necessity. If the sanction thus follows a predetermined set of circumstances, the traditional formulation of the "sanction" following the "delict" loses its moral and religious connotations which suggest that punishment is linked to wrong. In Kelsen's conception of the legal norm, the condition need not be human actions that can be interpreted as contralegal, but may be just conditions, facts, or circumstances (Sachverhalt, Tatbestand) to which the legal order attaches coercive consequences. If the specific meaning of "sanction" is limited to human actions and omissions which are delicts or "un-law" (Unrecht), Kelsen employs the still less morahty-colored term "coercive acts" (Zwangsakte) for those situations in which the conditioning facts of the coercive act are other than human actions or omissions. Every sanction is a coercive act, but not every coercive act is a sanction; just as every legal wrong is a condition of a coercive act, but not every condition of a coercive act is a legal wrong or delict.

By viewing unlawful behavior, the delict, as the condition of the sanction, Kelsen demythologizes basic legal thinking in a twofold manner. First, he removes the last traces of natural-law or ethical criteria from the concept of positive law, since legally prescribed or permitted behavior is not conceived as being posited or stipulated by the law as a positive command-in the sense in which this occurs in morabity or rehigion. In Kelsen's construction of the legal norm, the legal order does not command directly a certain type of beliavior. Instead, it attaches disadvantages-deprivations of life, liberty, or material goodsto the behavior which is the opposite of that desired by the legal order. The legal order does not command directly the kind of behavior that would be in conformity with the law nor does it prohibit directly the behavior that is unlawful. The behavior which is contrary to the law is

22. Id. at 41 . 
"downgraded," as it were, to the level of a mere condition. Only the coercive act, the sanction, ought to be.

Having entirely eliminated the ought from the first half of the structure of the norm-the unlawful behavior functioning as a condition of the sanction-Kelsen still keeps the ought in the second half of the legal norm-the sanction-but this ought has shed any affinity with a moral or natural-law ought and has become no more than a procedural or organizational ought: if certain behavior has taken place, the competent organ of the state is ordered to set the legal machinery in motion and apply the sanction as prescribed by law. In linking the ought of the legal norm to the state offical-the sanction-executing state organ-rather than to the totality of the members of society-the citizens-Kelsen achieves another measure of demythologizing legal and political concepts. In many traditional legal and political theories, the commands of the law are conceived as being addressed primarily to the members of the legal community as private citizens. Public officials, on the other hand, are viewed as the source of legal commands, primarily endowed with "powers" as contrasted with the "duties" of mere private citizens. In Kelsen's concept of the legal norm, the ought-element in the norm is addressed solely to the sanction-executing state organ. However, in line with Kelsen's general rejection of natural law, the ought addressed to the sanction-executing state organ is also free from any moral or natural-law connotation. It is an ought that grows out of the nature of the legal order as a coherent whole and functioning organizational system.

\section{Illegality and the Law}

Analyzing the nature of the delict and its relation to the sanction, Kelsen also rejects the traditional legal outlook according to which a negative moral value inheres in a delict and the sanction is viewed as something morally dishonorable. Kelsen objects to the traditional formulation according to which a sanction is attached to certain types of human behavior because they are dehicts. For Kelsen, the linkage is the reverse: a certain type of human beliavior is a delict because a sanction is attached to it: "From the point of view of a theory of positive law, there is no fact that by itself-that is, regardless of a consequence stipulated by the legal order-is a delict. There are no mala in se, but only mala prohibita." 23

In support of his position, Kelsen adduces two arguments, one theoretical, and the other, practical. Theoretically, the concept of an act bemg punishable because it is, by its very nature, a dehict, is based on

23. Id. at 112 . 
natural law and metaphysics, according to which negative values are immanent in certain actions and must therefore be punished. If one rejects the concept of "evil in itself" in the normative world as much as the "thing in itself" in the physical world, a human act can therefore be a delict only if a sanction or punishment is attached to it by positive law. From a practical viewpoint, there is the empirical phenomenon of some legal orders qualifying certain human acts as delicts whereas others fail to do so because of differences in value judgments with respect to the inorality or immorality of certain kinds of human behavior. Such moral divergencies also exist within the same legal community: acts to which sanctions are attached may be considered by some social or ideological groups morally defensible, yet from the perspective of law they must be considered as delicts, since sanctions are attached to them.

Kelsen's structural conception of the legal norm also helps to resolve the problem, or apparent problem, of how a norm can be said to be valid in case of illegal behavior. Ordinary language as well as legal terminology abounds in terms such as "illegality," Unrecht (unlaw), "breaking" or "violating" the law, and behind these words there is the idea that sucli behavior negates the law or that it stands outside the law, threatenmg or weakening its existence. Kelsen rejects this common conception on two grounds. First, there is the epistemological error of considering the relation between a legal norm prescribing behavior and actual contrary behavior as a logical contradiction. A logical contradiction can exist only between two propositions of the sane modality; in each of the two sets of propositions: " $\mathrm{A}$ is" and " $\mathrm{A}$ is not," or "A ought to be" and "A ought not to be," there is a logical contradiction, and only one can be true. But there is no logical contradiction between the propositions " $\mathrm{A}$ is" and "A ought to be." The statement that a person behaves in a certain manner and the statement that he ought to behave in a different manner prescribed by a norm are not logically contradictory. The is-statement is, or may be, true in the perspective of causality, and the ought-statement is, or may be, valid in the normative perspective.

This becomcs even more evident in Kelsen's second argument. For in his concept of the norn, the first half is constituted by the conditional illegal act, or delict, whereas the second half of the norm prescribes the sanction attached to the delict: "If $A$ (delict) is, B (sanction) ought to be." In Kelsen's concept of the norm, "the delict appears as a condition, not as a negation of the law; and this shows that the dehict is not a fact standing outside, much less in opposition to, the law, but a fact imside the law and determined by it-it shows that the law, according to its nature, refers specifically to this fact."24 In this line of

24. Id. at 113. 
reasoning, Kelsen employs again the neo-Kantian methodological approach according to which the method of cognition "creates" the object of cognition. From this viewpoint of legal science, illegality (Unrecht) can be understood only as law. Within this legal perspective, illegality or delict merely means that a certain kind of behavior is a condition of a coercive act as prescribed by a legal norm; conversely, lawful behavior is simply one which avoids sanctions.

\section{The Concept of Imputation}

The normative relation between the two elements of the legal norm-delict and sanction-is called by Kelsen "imputation" (Zurechnung). In expressing the cause-effect relationship in physical nature, causality is the scientifically recognized principle that connects events and processes. Human behavior, too, can be studied according to the principle of causality, as is done by the empirical social sciences. Yet acts of lruman behavior can also be linked with each other or with other facts by another principle, if the connection is through an "ought" rather than through an "is." Kelsen finds that so far there has been no generally accepted theoretical concept that denotes the principle that connects two sets of facts in a normative relation, and in searching for a proper term, he proposes "imputation." The concept of "responsibility" is too imprecise for Kelsen: the statement that a person is responsible for an action means that he may be punished for it, whereas in the case of an irresponsible person-a child or a lunatic-his action cannot be attributed or imputed to him. Traditional jurisprudence often expresses this relation between the individual and his action in the formula that a delict may not be imputed to a child or lunatic. Yet this formulation is untenable since the behavior of the irresponsible person-the child or lunatic-cannot be a delict at all. Whereas the concept of responsibility links the behavior to the person, imputation, by contrast, links a certain beliavior, the delict, to the sanction.

In defining imputation as the normative relation between delict and sanction, Kelsen further removes an element of inorality and naturallaw thinking implied in the traditional concept of responsibility. The concept of imputation links one type of behavior-the delict as the condition-with the sanction that ought to follow, and it serves as a procedural or organizational principle of connecting two sets of behavior in the legal system. The concept of imputation is also free from any residual causal elements in traditional jurisprudence, in which the sanction is conceived as in some way caused by the delict. Imputation establishes, or is, the normative relation between delict and sanction, although in actual fact the delict is not always followed by the behavior in the legal system. If a person has committed a delict, his delict 
or crime ought to be followed by punishment prescribed by law. Kelsen prefers this formulation to the traditional one, "The criminal ought to be punished," for the issue is not, "Who has committed the delict?" which is a question of fact, but "What sanction or punishment is to be imputed to the specific delict?" Just as Kelsen holds that in positive law there are no mala in se but only mala prohibita, one could say, by means of an analogy, that Kelsen's concept of "imputation" removes the notion of "the criminal" - with its existential and moralizing undertones-and replaces it with the morally neutral concept of a set of circumstances or specific delict that ought to be followed by a sanction.

The fundamental difference between causality and imputation is also reflected in Kelsen's approach to the complex relationships between determinism and free will. He rejects the widely held view that man is subject to a moral or legal order because his free will enables him to break the chain of causality and establish a new chain of conduct. According to this hypothesis, man's will is not the effect of other causes but only a cause which produces effects. Therefore, this view holds, if man fails to exercise his free will and to choose the right course of action, he is responsible for the moral disapproval or legal sanction consequent upon his morally wrong or legally delinquent behavior. Kelsen finds this explanation of free will unacceptable, for in the perspective of causality, there can be no event that is only a cause, inaugurating a new cliain of effects. Each cause of an act or event has a cause, which in turn has its cause, and so on in an infinite chain of causality.

In the perspective of causality, there can neither be a prima causa which is not also an effect, nor can there be a final effect which is not also a cause of further effects. Only in the normative-moral or legal-order can there be an end point of imputation, as when a sanction is imputed to a specific delict. In the perspective of a normative order, man is free to the extent that sanctions are imputed to certain types of behavior, although in the perspective of causality such behavior must be presuned to be causally determined. Far froin excluding causality, the linking of freedom and imputation presupposes it. The very establishment of a legal order influencing and regulating human beliavior is based on the assumption that man's will is a part of the cliain of causality. The function of a legal order is to induce men to be motivated by ideas in accordance with the conduct indirectly prescribed by the legal order. If the legal order performs this function effectively, men "will" what they legally ought to do, and their will thus becomes a cause of their actions in conformity with the law. The legal order thus presumes, not free will, that is, causal nondeterminancy, but causal determinacy. On that supposition, if a person acts illegally, a sanction is imputed to 
his delict. Kelsen thus reverses the usual formulation of the relation of freedom and imputation. The customary formula holds that man is "imputable" - or legally responsible-because he is free. Kelsen substitutes: Man is free because, and to the extent that, he is "imputable," that is, because legal consequences can be attached to his actions. In this conception, freedom and causality do not exclude each other, for the legal order assumes the casual determinacy of human behavior and therefore stipulates that certain kinds of action ought to be followed by prescribed sanctions.

\section{E. The Basic Norm}

From the beginning of his scientific career, Kelsen sought to construct a legal theory in which all legal phenomena could be viewed, not as a helter-skelter of uncoordinated individual norms, but as a system in which each norm would have its proper place. Whereas an is-statement is either true or false, depending on whether it conforms to reality, a norm cannot be either true or false, since it refers to behavior that ought to be. The norm is not "non-existent" or "unreal" but has a "specific existence" of its own-validity. The validity of a norm can be derived, not from the fact that something is, but only from another norm, and the legal system is made up of the sum total of such interdependent norms. The validity of a norm does not mean that it is, in fact, applied and obeyed, but that it ought to be applied and obeyed. The valid norm even assumes that actual behavior will deviate from the prescribed behavior, and this becomes nost evident in the case of illegal conduct. In a theft, for example, the norm against stealing does not lose its validity because the act of stealing has occurred, and the judge is required to apply the sanction against the debict in conformity with the norm. But even if the thief escapes and no judicial sanction can be prescribed and applied in fact, the norm still retains its validity, with respect to both the thief and the judge.

In ascertaining whether a specific norm is valid, one must inquire whether, and how, it is derived from another norm, which figuratively may be considered the higher norm. Thus, the individual norm against stealing applied by a judge against a thief is considered legal-validif it can be derived from a statute prescribing sanctions against the delict of theft. Seeking to ascertain why the statute designating theft as a delict is valid, one discovers that it, in turn, can be derived from the legal authority of the legislative body that has created the statute. The legal validity of the statutory acts of the legislative body must agam be derived from a valid norm: under the constitution, the legislative body is authorized to create such statutes. In seeking to ascertain the validity of the constitution, one finds that it cannot be derived from any 
higher legal source, since it is itself the highest legal source from which all other (lower) norms are derived. If the validity of the highest legal norm, the constitution, cannot be derived from anotler legal norm, it can only be derived from a nonlegal norm, or basic norm as Kelsen calls it. This basic norm is presupposed to be valid but is not itself a norm of positive law. Kelsen formulates the basic norm as follows: "Coercive acts ought to be performed under the conditions and in the manner in which the historically first constitution, and the norms created accordmg to it, prescribe. (In sliort: One ought to behave as the constitution prescribes.)"25 Without sucli a presupposed norm conferring validity upon the constitution, the latter would have no legal cliaracter, and the norms below the constitution-legislative, judicial, and executivewould have no legal character either, since a 11orm can be derived only from another norm.

The concept of the basic norm fulfills several functions in the Pure Theory of Law. Kelsen is aware that, as a normative system, the legal system needs a "cut-off point" in the quest for validation. ${ }^{20}$ Whereas in the realm of physical nature the quest for the cause of an effect leads to a regressus ad infinitum, the unique characteristic of a normative order is that the quest for the validity of a specific norm must end in a highest norm which is not posited or created by the highest norm-creating authority but presupposed by cognition. In the normative order of religion, for example, the question of the validity of norms posited by God arises and the answer is also to be found in a presupposed basic norm. Theological ethics, in tracing the validity of the divine norm, "Honor your parents," must end up by presupposing a basic norm, "One ought to obey the commands of God." This norm cannot be presumed to be created by theological ethics, because it would then set itself up as a norm-creating authority above God, validating his norms. Nor can the issue of validity be solved by presuming that God himself posited the norm, "One ought to obey the commands of God," because this would still leave unresolved the question of from what other norm it could be derived. Theological ethics, therefore, must presuppose the validity of the basic norm, "One ought to obey the commands of God," and from the basis of this presupposition specific norms emanating from God then derive their validity.

From an epistemological viewpoint, too, the basic norm of the legal system fulfills an important function. As pointed out above, Kelsen views as one of the primcipal characteristics of the norm its function as a scheme or method of interpretation, allowing the decision of whether,

25. Id. at 201.

26. For a more general discussion of the problem of "limiting" questions in philosophy and ethics, see S. TOUIMIN, REASON IN ETHICS 204 (1960). 
and to what extent, the subjective meaning of specific human conduct can be interpreted as having objective meaning, or legal validity. The basic nonn performs this function of a scheme of interpretation for the legal order as a whole, for only the presupposition of the basic norm makes it possible to interpret the constitution and all norms created according to the constitution-the whole legal order-as legally valid. Epistemologically, Kelsen therefore refers to the basic norm as "the constitution in a logical sense of the word" 27 or as "the transcendentallogical condition"28 of interpreting a inultitude of certain phenomena as objectively valid legal norms. Kelsen suggests that his concept of the basic norm is analogous to Kant's transcendental-logical primciples of cognition-time, space, and causality. Just as knowledge of the empirical world cannot be derived from these principles or categories of cognition, but merely by means of them, so the content or specific norms of positive law cannot be derived from the basic norm but can merely be understood through the presupposition of the basic norm. The basic norm supplies the validity of the legal order but not its content, and, therefore, the validity of a legal order cannot be denied on account of its content.

\section{F. Limits of Legal Positivism}

The basic norm also supplies the legal order with a principle of unity. It makes possible the consideration of a norn as legally binding if the norm can be integrated into an entire system of norms, ultimately deriving its validity from the presupposed basic norm. As the source of validity common to all norms of a legal order, the basic norm is thus also the source of their unity.

The concept of the basic norm as the source of validity of a system of positive law raises two problems reflecting the limits of positive law and of a positivistic theory of law. First, there is the problem of the relationship of the basic norm to natural law. According to the theory of natural law, the validity of the positive law rests, not on norms of the positive law, but on outside norms-norms set by natural'law. If the positive law does not conforn to the norms of natural law, then the positive law nuust be regarded as invahid. The basic norm, too, Kelsen concedes, ${ }^{20}$ is not a norm of positive law, but a presupposed norm, and yet the validity of positive law is derived from it. He recognizes that there is a limit to legal positivism insofar as the validity of the legal order depends on an extra-legal norm.

27. H. Kelsen, supra note 12, at 199.

28. Id. at 202.

29. Id. at 219. See also H. KELSEN, supra note 18, at 437. 
Yet, on balance, Kelsen feels that the difference between such a positivistic theory of the law and a theory of natural law is greater than the similarity. In the first place, a positivistic theory such as the Pure Theory of Law merely employs the basic norm as a cognitive device so that a mass of legal materials can be understood as a meaningful legal order, whereas the theory of natural law seeks to formulate and establish a just legal order, superior to, and independent of, the positive legal order. Secondly, Kelsen defends the use of the basic norm-outside of the positive law-to establish a science of positive law by analogy with the Kantian dilemma. Kant's transcendental-logical categories make empirical knowledge of the pliysical world possible, and yet they themselves are not data of experience, and have therefore often been called metaphysical. If Kant's categories thus involve a minimum of metaphysics, Kelsen admits that the basic norm contains a minimum of natural law, but only in the Kantian transcendental-logical sense, since the function of the basic norm is to make possible the cognition of positive law and the formulation of a science of positive law. Because the Pure Theory of Law seeks to analyze and assess the ultimate assumptions and limitations of legal theory, Kelsen calls it-by analogy with Kant's critical philosophy—a "critical positivism." 30

The second major problein raised by the conception of the basic norm is the relation of the legal order to its effective operation. Although the basic norm is presupposed, it is not arbitrarily presupposeda "free invention"-for the constitution upon which it directly confers validity as well as the coercive order set up according to the constitution must on the whole be effective. Kelsen views the Pure Theory of Law as occupying a middle ground between two extreme theories. One extreme theory-tending toward an uncomproinisingly idealistic stance-postulates that the validity of the law is completely independent of its effectiveness, since there is no connection between the "ought" of validity and the "is" of effectiveness. The other extreme theory, tending toward a realistic outlook, assumes that validity and effectiveness are identical. Kelsen rejects the first theory on the ground that a legal order is no longer valid when it ceases to be effective; also, the very creation of a legal norm presumes a norm-setting act-so that there must be some relation between the "is" of the norm-creating act and the "ought" as the meaning of the norm. As to the second theory, Kelsen argues that effectiveness is a condition of validity but not identical with it. A norm, for example, may be valid before it has ever been applied, and its validity is not necessarily impaired by the fact that it is occasionally not obeyed or apphed. The effectiveness of a legal order is neither identical with its validity nor the reason for it. The reason for the

30. H. KeLSEN, supra note 18, at 438. 
validity of a legal order is the presupposed basic norm, according to which one ought to behave in conformity with an actual constitution which is, on the whole, effective. The basic norm thus includes two factual conditions: First, that an actual constitution has been created, and, second, that it is by and large effective.

\section{G. The Tension Theory}

Kelsen's view of the relationship between the validity and effectiveness of the legal norm and of the whole legal order is nost aptly clarified by his conceptualization that tension inevitably inheres in the relationship between norm and actual behavior-between "ought" and "is." Unless such tension exists, a normative order-including a legal order-can hardly be said to exist. An absence of tension between a normative order and actual human behavior is imaginable only with respect to a normative order that prescribes only conduct that actually takes place. A norm, "You ought to do what you actually do," nnay look linguistically like a norm, but is, in fact, a mere description of the behavior that actually takes place. Such a construction is particularly unsuited to the legal norm, which includes, in its first half, the delict as a condition which ought to be followed by a sanction. The legal norm does not state, "You ought to behave as you actually behave," but, "If you behave contrary to the law, a sanction ought to follow." The legal norm, in other words, presumes that there always will be a tension between the norm and actual conduct, and coines into effect precisely when contra-normative, or illegal, behavior occurs.

For a legal order to have ineaning, therefore, the tension between norm and conduct inust not fall below a certain minimun, although Kelsen nowhere spells out what this minimum of tension would be. Similarly, the tension between norm and actual conduct inust not rise above a certain maximum, because if it does, the legal order may be said to be no longer effective and thus lose its validity-although here, again, Kelsen does not spell out in detail how such a maximum gap between legal order and actual behavior can be defined or measured. ${ }^{31}$

In most cases, it should not be too difficult to decide whether a legal order has ceased to be effective so that it is no longer valid. For example, after the revolutionary overthrow of the Tsarist constitution in 1917 and the subsequent establishment of Soviet rule it was ineaningless to interpret acts of citizens or state organs from the viewpoint of Tsarist law. Since the new Soviet legal order was effective, the old basic norm, "One ought to behave as prescribed by the Tsarist con-

31. See W. Friedmann, Legal Theory 278 (5th ed. 1967): "How this minimum of effectiveness is to be measured Kelsen does not say, nor could he do so without going deep into questions of political and sociological reality." 
stitution," had been replaced by a new basic norm taking into account the fact that the new Soviet legal order was in effect. However, there may be marginal cases, in which determining a basic norm may not be so simple. In a civil war, neither of the combatant sides may be in effective control of the whole national territory or even of specific major areas. During the Vietnam war, for example, it has been frequently stated that in some areas the law of the government of South Vietuam was effective in the daytime, but that the law of the Viet Cong was effective during the night. Which basic norm is to be chosen in such a confused situation?

While Kelsen does not pretend that the concept of the basic norm provides accurate standards of measurement that can be applied in each marginal situation by means of sheer arithmetic, the basic norm does reflect the general scientific principle of "cognitive economy." According to this principle, physical laws are constructed under the postulate that the largest possible number of facts be explained by the simplest possible formula. Similarly, in the normative sphere, that basic norm should be presupposed which will allow the largest number of behavioral phenomena to be subsumed under the legal order that seeks to regulate them. In most cases, the application of this principle should offer no serious difficulty. In marginal cases, quantitative analyses of the prevailing patterns of behavior would have to provide the factual element which is implied in the basic norm. Just as Kelsen is willing to admit that the concept of the basic norm contains a minimal element of natural law-inasmuch as the validity of the legal order is derived from a norm outside of positive law-he also concedes that the basic norm, to be meaningful, must take into account a minimum of social facts, or social reality. Thus the concept of the basic norm and that of the indispensable tension between norm and behavior supplement each other: the concept of the basic norm seeks to solve the problem of validity of law; the tension concept, the problem of its positivity.

\section{H. Law as a Dynamic Process of Gradual Concretization}

The concept of the basic norm led Kelsen to one of the most fruitful conceptions of the Pure Theory of Law: the view of the law as a $d y$ namic process of norms linked together in a hierarchical relationship. In German, Kelsen uses the term, der Stufenbau der Rechtsordnung, which his translator renders as "the hierarchical structure of the legal order."32 But the theory of Stufenbau can also be expressed in English as the "steps-and-stairs" theory of the law or as "the gradual concreti-

32. H. KELSEN, supra note 12 , at 221. 
zation" of the law. None of the three renditions in English fully reflects all three basic elements of the Stufenbau concept: that the law is a process, always in statu nascendi; that this dynamic process of concretization from the general to the particular is gradual, in steps, as it were; and that the various legal norms created in this process are lield together in a hierarchical relationship.

Depending on the nature of the basic norm, a system of norms is either static or dynamic. In a non-legal normative system, the basic norm is static and material; this means that particular norms can be discovered by an act of thought. In the normative system of morals, for example, the basic norm of prescribing truthfulness allows us to deduce, through a logical operation, specific norms, such as not to lie, clieat, or renege on one's promises. The content of the specific norms in such a system is predetermined by the content of more general norms, and-ultimately - the content of the basic norm. By contrast, the basic norm of the normative system of positive law is dynamic and formal, or procedural. It contains only the determination of a norm-creating fact, the rule which stipulates how the posited-positive-norms of the legal order are to be created. As put by Kelsen:

The basic norm of a legal order is not a material norm which, because its content is regarded as immediately self-evident, is presupposed as the highest norm and from which norms for human behavior are logically deduced. The norms of a legal order must be created by a specific process. ${ }^{33}$

More succinctly still, Kelsen defimes the basic norm as "the presupposed starting point of a procedure: the procedure of positive law creation." 34 To be valid, norms created according to the basic norm need satisfy no material or substantive standard but can have any content whatsoever provided they have been created in the prescribed manner. The question, therefore, whether a specific legal norm is valid can be resolved only by ascertaining whether it has been created in a manner prescribed by another norm. The relation between the norm determining the creation of another norm and the norm created accordingly may be viewed - in a figurative mamier-as that between a higher and lower norm. The whole legal order is thus viewed, not as a static system of norms coordinated through the principle of equal status, but as a pyramidal hierarclyy of higher and lower norms in a dynamic system of constant creation of law through the gradual concretization of higher norms in lower ones. The hierarchical structure of the legal order culminates im the basic norm, the starting point of the process of creating law.

Most legal norms both apply and create law. The constitution ap-

33. H. KeLSEN, supra note 12, at 198.

34. Id. at 199. 
plies a norm in relation to the basic norm but creates law in relation to the legislative body. The legislative body applies law in relation to the constitution but creates law in relation to the judiciary and the executive. The executive or judicial organ applies the statutory law but creates administrative or judicial norms. Only the first and the last stages of the legal process are necessarily not dual in character. The basic norm as a presupposed norm is pure creation of law, not applying any superior norm. At the other end of the legal system, the execution of the legal sanction in a concrete case is pure application of law, without creating new norms.

If, apart from the basic norm and the final act of law enforcement-or obedience to the law-every legal norm is both applying and creating law, the higher norm appears as a frame within which several more specific lower norms may be created. The difference between the legislator and the judge is quantitative rather than qualitative. In the case of the legislator, the superior norm-the constitution-prescribes mainly the procedure of creating statutory law, altlough some determination of content, too, nnay be mcluded-such as listing fundamental rights and liberties removed from legislative interference. In the case of the judge, the superior norm-the statute-also preseribes the content and the boundaries of the frame within which he may move, but in either case the legislator or judge has discretion with respect to the manner of creating the lower norm. The act of filling the frame of the superior norm is an act of will rather than of intellect, a political act rather than a cognitive one. In choosing one of the possible interpretations or applications of the superior norm-the constitution in the case of the legislator and the statute in the case of the judge--both legislator and judge act as politicians, not as logicians. This stress on the alogical element in the process of creating law was anticipated, before the Pure Theory of Law, by Justice Homes when he spoke of the fallacy "that the only force at work in the development of law is logic," and emphasized that the alogical element is "the very root and nerve of the whole proceeding." 35

\section{Integrating Civil-Law and Common-Law Approaches into a Unified Theory of Law}

The dynamic, multi-dimensional elements of the Stufenbau analysis enable the Pure Theory of Law to overcome traditional weaknesses of both continental and Anglo-American legal theories, and to provide, perhaps for the first time, the structure of a unified legal theory that integrates legal phenomena of diverse legal systems into a whole. The

35. Holmes, The Path of the Law, 10 HARv. L. Rev. 457, 465-66 (1897). 
chief characteristic of older, traditional legal theories as well as of newer, more recent ones may be that they all regard the law from a one-dimensional viewpoimt. The older theory, still dominant in civil-law countries, conferred a privileged, monopolistic status upon the statute, going frequently so far as to identify law with statute. This statuteoriented view of the law minimizes, or fails to perceive, the legal quality of phenomena both above and below the level of the statute. Constitutional law becomes more or less transformed into customary statutory law, whereas the legal phenomena below the level of the statute are viewed as mere application of the law, as in judicial or administrative decisions; as mere legal relationships, as in debor-creditor relations; or as mere empirical facts, as in the enforcement of the law. The identification of law with statute also has an ideological-political point, as becomes evident in the traditional German equation of Rechtsstaat and Gesetzesstaat, identifying the supremacy of the rule of law with the creation of statutory law through a legislative body elected on the basis of a democratic political system.

In contrast with the older, statute-oriented legal theories-mostly dominant in civil-law countries but also presented by some coinmon-law jurists sucli as Austin-the newer theories of law claim an exclusive, or at least major, role for the judicial decision. While mainly identified with the realist and behavioral schools of jurisprudence in the United States, this decision-oriented school has also had its adherents in continental Europe in the "free law" movement, as represented by Fuchs and Kantorowicz in Germany and by Gény in France. According to this decisionist emphasis, there is little or no legal value or quality in legal phenomena above and below the level of the judicial decision. For extreme realists like Frank and Llewellyn there is hardly law at all before the stage of the judicial process. Law for them is the judicial decision: legal phenomena above this level, like statutes or rules derived froin case law are not law but "merely words."38 Legal phenomena below the level of decision, such as the act of enforcing the law or carrying out the sentence, are in this view even less relevant than in the traditional theory emphasizing statute law.

The decisionist emphasis, like its statute-oriented counterpart, has an ideological-political aspect. Whereas the decisionist emphasis has been used by both conservative and liberal legal theorists, its main function-particularly since the 1930 's-has been to counterbalance the Inore conservative leanings of Congress and state legislatures with the more liberal orientation of the courts, particularly the United States

36. J. Frank, LAW AND THE MODERN MIND 125 (1930). See also K. LleWELLYN, The Bramble Bush 3 (1930) ("What these officials do about disputes is, to my mind, the law itself.") 
Supreme Court. Both the statute-oriented and the decision-oriented theories of law have been, and still are to some extent, chapters in the constitutional struggles of various countries. On the Continent, the emphasis on statute served the political purpose of asserting the independence of presumedly more liberal parliamentary bodies vis-à-vis presumedly more conservative monarchs or republican executives, whereas in the United States-but less so in Britam-the emphasis on the judicial and administrative decision strengthened liberal politics vis-à-vis presumedly more conservative legislative bodies.

Quite apart from the ideological-political elements in both the statute-oriented and the decision-oriented legal analyses, it is certainly no accident that continental jurisprudence emphasizes the statute, while American, and to some extent also Enghish, jurisprudence stresses the judicial decision as the dominant-or sole-form of law. It is simply a case of theory reflecting the respective legal systems. In an atunosphere of almost wholly written and codified law, as on the Continent, it is understandable that the form of the statute should be considered as the universal legal form. On the other hand, in a legal system in which judicial decisions have as much power and authority as they do in the United States and other common-law countries, the judicial decision would be expected to dominate the juristic perspective. Understandable as these one-dimensional perspectives are, they are unable to construct a general legal theory and remain essentially descriptions of particular legal systems. By contrast, the Pure Theory of Law is free from both ideological-political burdens and particularistic analytical emphases. As to the former, from the presupposition of the basic norm on, the Pure Theory of Law insists that the moral or political content of the law does not affect the problem of normative validity, and that the law as a coercive order of human behavior can have any moral or political content: capitalist or socialist, democratic or totalitarian, religious or agnostic, individualistic or collectivist.

Regarding the particularistic one-dimensionalism of both statuteoriented and decision-oriented legal theories, the Pure Theory of Law does not reject either theory as false but considers both to be half-true. The statute-oriented conception of law is correct in insisting on the legal character of statutory law, but fails to comprehend that courts and administrative agencies also create law. The fixation of the statuteoriented emphasis on the legislative body as the sole source of creating general norms is particularly refuted by the fact that courts, too, can create general norms by establishing precedents, as is generally done by the highest court in a legal system. The half-truth in the decisionoriented jurisprudence is its realization, colored as it may be by moralpohtical considerations, that courts do create law. But this approach 
misses the other half-the fact that "the judicial decision is the continuation, not the beginning of the law-creating process." ${ }^{37}$ In its dynamic conception of the law as gradually concretizing itself in a constant process of self-creation, the Pure Theory of Law is thus able to retain what is tenable in both the statute-oriented and the decisionoriented theories of law while at the same time filling in the gaps in both approaches. If the Pure Theory of Law is not as yet the first general theory of law, it is at least the most successful attempt in that direction. $^{38}$

\section{III}

\section{IMPLICATIONS FOR POLITICAL THEORY}

The implications of the Pure Theory of Law as a metlod of analysis that is more coinprehensive and therefore more reahistic than previous methods of systematizing the world of legal phenomena are also farreaching for political theory, particularly with respect to the basic and classical problem of the types, or forms, of government. The traditional doctrine of the forms of government, from Aristotle to the present, divides governments into republican and monarchical, democratic or autocratic, and the problem of the form of government is presented entirely in the perspective of the organization and procedure of the legis-

37. H. Kelsen, supra note 12, at 255.

38. Friedmann argues that the legal structure of modern totalitarian states such as National Socialism or Fascism is not accounted for by the Pure Theory of Law and its Stufenbau analysis, because such states had no clear hierarchy between statute, administration, judicial decision, and other sources of law.

Law courts are directed to disregard the expressed norm of a statute, if it seems incompatible with the political ideals of National Socialism. Administration, judicial decision and other manifestations of law are all supposed to be inspired by the will to realize National Socialism as personified by the leader. In this task they rival with each other, but are not superior to one another.

W. FrIedmanN, supra note 31 , at 286 . While it is true that under the Nazi regime in Germany-but much less so under Fascism in Italy-the existence of two hierarchiesstate and party-resulted in a more complicated Stufenbau than in states (democratic or authoritarian) in which only one hierarchy-that of the state-exists, the con" cretization of law can still be accounted for by the Stufenbau analysis. If one presumes, as does Friedmann, that obedience to the leader was the basic norm from which the Nazi legal order derived its validity, the question must first be settled whether the basic norm referred to Hitler as the head of the Nazi Party or as the licad of the state. If one presumes the first alternative to have been the correct one, then the norms of party officials would take precedence over those of government officials, and within the ranks of party officials the norms created by higher officials would be superior to those of lower officials. Friedmann's argument corroborates the point that the choice of the presupposed basic norm is not always easy-a point which Kelsen recognizes but which he nowhere spells out in sufficient detail. For a concise statement of soine of the problems relating to the basic norm, see Kelsen, On the Basic Norm, 47 CalIF. L. REv. 107 (1959). 
lative authority as determined by the constitution. From Aristotle to the present day, this identification of political will-formation with legislative power lias remained the cornerstone of the doctrine. It is simply the transference from the legal to the political field of the identification of law with statute.

However, in the light of the Pure Theory of Law, and particularly its Stufenbau analysis of the entire legal process, legislation-or pobitical will-formation on the legislative level-is only one stage in the lawmaking process, and a more accurate determination of the forms of state can only be established by an analysis of the law-making stages above and, particularly, below that of legislation. In political terms, the issue on all levels of decision-making-legislative, judicial, and executive-is to what extent the individual has participated in the making of decisions affecting him. As a natter of primciple, it may be conceded that the form of state, as defined by the constitutional determination of the law-making powers and procedures of the legislature, cannot be fundamentally altered by the divergent law-creating rules of the courts and the executive, for both are subordinate to legislation. However, the modifications introduced by the judiciary and the executive may be sufficiently significant to affect substantially the character of a polity.

Taking into account the stages of political and legal norms and obligations on all levels, one finds that the traditional classification of states into simple opposites like autocracy and democracy, inonarchy and republic, is inadequate. We could describe as deinocracies or autocracies, states whose legislatures, judiciaries, and executives were of a consistently democratic or autocratic character. But such uniformly consistent forms of state have rarely existed in the world of historical experience. There are numerous states in which legislation is absolutist or authoritarian, administration-central or local-has elective elements, and the courts have such democratic elements as the jury. France under the Third and Fourth Republics was a classic illustration of a state with a radically democratic legislative body and process, but with a highly centralized and authoritarian administrative machinery. Simlarly, in the case of the Weimar Republic in Germany the form of government was transformed-on the constitutional and legislative levelsfrom an authoritarian monarchy into a democratic republic. Yet, the personnel and organization of the pre-republican administration and judiciary were taken over by the new regime without much change, and their anti-democratic attitudes contributed considerably to the eventual destruction of the Weimar experiment in democratic government.

Of the many other insights supplied by the multi-dimensional, dynamic methodology of the Pure Theory which are of great interest to 
the legal and political theorist, only two, for reasons of space, can be referred to at this point: the dualism between public and private law and the conception of property. ${ }^{39}$ With respect to both problems, traditional legal and political theory has employed two chief criteria: interest and power. According to the interest theory, already clearly expressed in Roman law, public law is that which refers to the collective interest, private law that which refers to the individual interest. As stated in the Institutes of Justinian: "publicum jus est, quod ad statum rei Romanae spectat, privatum, quod ad singulorum utilitatem pertinet." ${ }^{\prime \prime}$ Kelsen rejects this teleological criterion on two grounds: First, every legal norm serves both collective and individual interests; and second, the applicability of teleology is, from a legal viewpoint, highly doubtful, for "the purpose served by legal norms lias as little relevance to their legal quahity as price has to the classification of paintings." 41

More important than the interest theory is that whicli characterizes the distinction between public and private law as one between relations of power and relations of law. Kelsen argues that this dualism is not theoretical but ideological. Froin a legal viewpoint, particularly as reflecting the inulti-dimensional, dynamic methodology of the Stufenbau theory, the difference between public and private law is not that between law and non-law, but between stages of the law at different levels of creation. To be vahid law, norms of both public and private law inust be derived from higher norms of the legal order. The ideological function of the absolutist distinction between public and private lawmore entrenched in civil-law than im common-law countries-has been to keep alive the maxim of the public law of imperial Roine as later "received" by continental Europe: princeps legibus solutus est. This maxim, later transformed imto the doctrine of raison d'état, allows the ruler or rulers to violate the law whenever the interests of the stateor what the rulers think are the interests-are at stake. ${ }^{42}$

From the political viewpoint, the ideological function of a sharp distinction between public and private law is to create the impression

39. For a fuller treatment of the applications of the Stufenbau theory, see W. EBENSTEIN, THE PURE THeORY OF LAW 157-206 (1945, re-issued 1969).

40. INSTTTUTES 1.1.4.

41. H. Kelsen, Allgemeine StaAtslehre 81 (1925).

42. Interestingly enough, Anglo-American legal theory and jurisprudence have traditionally been opposed to the concept of "state necessity" as a legal concept. In the words of Chief Justice Camden: "[W]ith respect to the argument of state necessity, or a distinction that has beeu aimed at between State offences and others, the common law does uot understand that kind of reasoning, nor do our books take notice of any such distimctions." Entick v. Carrington, 19 St. Tr. 1030 (1765), cited in D. Keir \& F. Lawson, Constituttonal LaW 153 (1933). See also C. Merriam, Public and Private Government (1944) (exposing, from the standpoint of political theory, the fallacies of identifying government with public government). 
that relations of control and domination are only present in public lawthat it alone is political-while presenting private law as being non-political, or free from problems of control and domination. Kelsen rejects this distinction between public law that is political and private law that is not, as incorrect, for the "private" rights created by contracts, for example, are "just as much the theater of the political dominion as the public law created by legislation and administration." ${ }^{43}$

Kelsen sees in the legal institution of private property the core of private law, which is the specific technique of the capitalist order of producing and distributing goods: "This is an eminently political function of power." ${ }^{44}$ However, Kelsen points out that the ideological defimition of property as consisting of a technical relation between inan and things rather than of a political relation of domination of inan over man is also inherent in the Marxist interpretation. For Marx and Marxians, only privately owned property entails control and domination of man by man, whereas in a system of collectivized property the "state would wither away" and the domination of man over inan would be replaced by the "administration of things." Kelsen considers the Marxist identification of collective property with man's relation to things just as ideological as the corresponding bourgeois.identification of private property with man's relation to things, for "there can be no direction of the processes of production which is not also government of persons-that is, motivation of one lluman will by another, or power of man over man." 45

\section{CONCLUSION}

Throughout his career, Kelsen has reinained faithful to the neoKantian standpoint according to which the method of cognition deterinines or "creates" the object of cognition. Therefore, one of his main objectives has consistently been to defend the "purity" of the Pure Theory of Law against two areas of methodological syncretism into which legal analysis has often been drawn: psychology and sociology on the one land and ethics and politics on the other. Early in his career, Kelsen rejected the possibility of a sociology or psychology of law, since law is to be conceived as a normative order. Later he conceded that a sociology of law is possible, if the object of inquiry is social facts rather than norms. The sociologist, for example, can investigate the ideological, political, or economic motives and interests that have induced a legislative body to create a particular kind of law, what ef-

43. H. KeLSEN, supra note 12, at 283.

44. H. KELSEN, REINE RECHTSLEHRE 114 (1934).

45. Kelsen, Allgemeine Rechtslehre im Lichte materialistischer Geschichtsauffassung, 66 ARCHIV FÜR SOZTALWISSENSCHAFT UND SOZIALPOLITTK 449, 511 (1931). 
fects such statutes have, and to what extent human behavior has been motivated by the intentions of the legislators in creating legal norms. In all such empirical investigations, Kelsen argues, sociology or psychology deals, not with law as a normative system, but with phenomena that are parallel to the law.

Yet, on the basis of Kelsen's own premises it can be argued that the issue of the parallel relation between norm and fact is also of some concern to the legal theorist. While Kelsen insists that the effectiveness of a norm is not identical with its validity, he does stress that there is an important relation between the two, for a wholly ineffective norm loses its validity, just as a complete legal order must have an empirically verifiable relation to effectiveness, a point made by Kelsen with particular vigor in discussing the choice of the presupposed basic norm. It is a moot point, at this juncture, whether Kelsen's battle against methodological syncretism will be generally accepted by legal theorists of the coming generations. In any event, it has not been an issue (as Kelsen admits in the Preface to the second edition of Reine Rechtslehre) that has excited the minds of his critics and opponents to the point of frenzy.

As time went on, the defense of the purity of the Pure Theory of Law against the second area of methodological syncretism-ethical and political intrusions-increasingly seemed to Kelsen, and to his critics and opponents, the more inportant of the two. The political use and abuse of social science and of legal theory and jurisprudence in totalitarian communist and fascist regimes strengthened Kelsen's conviction that scientific inquiry must be kept free from any kind of political intrusion in the form of natural-law doctrines, conservative apologias, or revolutionary challenges of positive law. The theoretical analyst of the social or legal order is not a political authority whose task is to remake society, as is increasingly argued by the New Left that urges the "politicization" of scholarship and the university. The task of the social or legal theorist is to know, to understand society and the legal order, and not to clothe his own political prejudices or value preferences-or those of others-in the language of analytical objectivity. Rational cognition cannot resolve conflicting value preferences, because they are based on volitional and emotional rather than cognitive factors.

This position of philosophical relativism-in both the theory of knowledge and the theory of values-has often brought forth the charge that sucli relativisin is amoral or immoral in the sense of denying the existence of values. Relativisin, Kelsen holds, does not claim that there are no values but only that there are no absolute values demonstrable by cognitive verification. Relativisin thus coinpels the individual to inake his own choice between conflicting value systeins, and makes it impos- 
sible for him to surrender his moral responsibility to a superior moral or religious authority.

Although Kelsen's seminal contributions to legal theory now span a period of over 60 years, the importance of his work cannot be adequately assessed without the benefit of the perspective of coming generations. The anti-metaphysical orientation in his theory of knowledge as applied to his theory of law places him squarely in the tradition of modern thought that is identified with John Loeke, David Hume, ${ }^{46} \mathrm{Im}$ manuel Kant, and Bertrand Russell. In particular, Kelsen has felt a close affinity to Kant's thought, although he has been convimced that Kant's pioneering work in the philosophy of the physical sciences needed to be carried on and completed in the field of the normative sciences. Just as, regardless of whether one accepts Kant's philosophy of science, one cannot bypass it, so that all philosopliy after Kant can only bepositively or negatively-post-Kantian, there is good reason to believe that in future generations all legal theory will have to come back-critically or affirmatively-to Kelsen's work as the starting point of a new era of legal science.

46. D. LIOYD, InTRODUCTION to JURISPRUdENCE 187 (rev. ed. 1965). Lloyd contends that Kelsen's theory of knowledge goes back to Kant, but that in his treatment of natural law "Kelsen is a positivist of positivists, whose real spiritual father is Hume, rather than Kant." 